This article was downloaded by: [Temple University Libraries]

On: 11 January 2015, At: 23:59

Publisher: Routledge

Informa Ltd Registered in England and Wales Registered Number: 1072954

Registered office: Mortimer House, 37-41 Mortimer Street, London W1T

3J H, UK

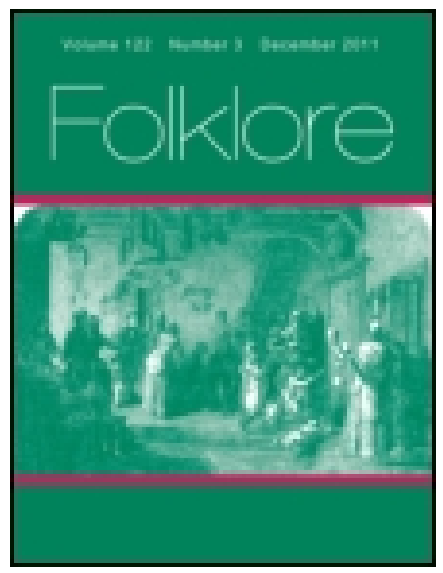

\title{
Folklore
}

Publication details, including instructions for authors and subscription information:

http:// www. tandfonline.com/loi/ rfol20

\section{The Chinese Isles of the Blest.}

W. Perceval Yetts

Published online: 01 Feb 2012.

To cite this article: W. Perceval Yetts (1919) The Chinese Isles of the Blest., Folklore, 30: 1, 35-62, DOI: 10.1080/ 0015587X.1919.9719077

To link to this article: http:// dx. doi. org/ 10.1080/0015587X.1919.9719077

\section{PLEASE SCROLL DOWN FOR ARTICLE}

Taylor \& Francis makes every effort to ensure the accuracy of all the information (the "Content") contained in the publications on our platform. However, Taylor \& Francis, our agents, and our licensors make no representations or warranties whatsoever as to the accuracy, completeness, or suitability for any purpose of the Content. Any opinions and views expressed in this publication are the opinions and views of the authors, and are not the views of or endorsed by Taylor \& Francis. The accuracy of the Content should not be relied upon and should be independently verified with primary sources of information. Taylor and Francis shall not be liable for any losses, actions, claims, proceedings, demands, costs, expenses, damages, and other liabilities whatsoever or howsoever caused arising directly or indirectly in connection with, in relation to or arising out of the use of the Content.

This article may be used for research, teaching, and private study purposes. Any substantial or systematic reproduction, redistribution, reselling, loan, sub-licensing, systematic supply, or distribution in any form to anyone is 
expressly forbidden. Terms $\&$ Conditions of access and use can be found at http://www.tandfonline.com/page/terms-and-conditions 


\section{THE CHINESE ISLES OF THE BLEST.}

RY MAJOR W. PERCEVAI. veTtS.

AN alternative title for this paper might suitably be "A Study in Universal Folk-Lore "; for the subject offers not merely a fascinating page in oriental myth and legend, but something common to all races in their imaginings of a happy Otherworld, and I propose, while investigating an ancient Chinese belief, to driw some analogies between Eastern and Western tradition.

We are about to enter a realm little explored by occidentals, a world of wizards, alchemists, and sea-going adepts, all reputed devotees of a many-sided cult known by the name of Tnoism. It is thercfore not irrelevant to make by way of preface a few remarks about the meaning of the word Taoism. In its primitive sense it denotes a religion of the workings of the Cosmos, of Nature as a whole. Taoism conceives the universe as one vast organism, the power and activities of which are centred in the "Ultimate Principle" or the "Great Absolute" spontaneously manifesting itself in two opposite Regulating Forces-the $Y_{i n}$ and the Yang. The creation, continuance of existence, or decay of all things depend upon the interaction of $Y$ in and Yang. Man, as a component of the Cosmos, is subject to the dual power, both spiritually and materially; and bence it is of supreme importance that he should shape his thoughts and deeds in conformity with $T A O$, or the Course of Nature. Moreover, he is even able by certain methods to modify Nature's laws in his own favour, and thus succeed in transcending the limitations of ordinary mortals. 
Many and varied are the means to this end employed by the Taoists. They ransack the vegetable and mineral kingdoms for objects possessing the sought-for magic power; they bring the alchemist's crucible into use in order to prepare drugs of immortality and elixirs of life; they subject themselves to all kinds of ascetic discipline, mental and physical. And the efficacy of each method is proportional to its effect in bringing about assimilation of the vital principles $Y$ in and $Y$ ang in felicitous combination. They who are successful in the quest "attain TAO" (as the Chinese express it), thus reaching a superhuman plane of existence where earthly trammels no longer bind them. The more perfect adepts are translated to heavens in the sky, or even "take their place among the stars." 1 But the great majority-the general rank and file, called hsienare relegated to less exalted abodes. Many remain for varying periods of time among the haunts of men, to escape at last, after many centuries it may be, to one of the Taoist paradises on earth, chief among which is the group of islands that form the subject of this paper.

This cult of deathlessness, that has to do with the making of hsien, so intimately penetrates the island Elysium conception that I propose to consider it rather fully. A knowledge of how and when a mortal becomes a hsien is a necessary first step towards a clear understanding of the Isles of the Blest.

The transformation of an ordinary man into a hsien may take place without any visible bodily change, and its happening may be no less sudden than the change known as " conversion" among our revivalists. True, sometimes it is preceded by mental or physical preparation, or by a combination of the two; but the actual passing over the threshold occurs at a moment of supreme spiritual illumination, or on the swallowing of some magic nostrum, or by virtue of a charm, or by an act of favour on the part of one of the

\footnotetext{
'Chuang Trü, S.B.E. xxxix. p. 245.
} 
semi-divine saints of $T A O$. That the spiritual or intellectual factor is non-essential is proved by accounts of the brute creation participating in the transformation. All this makes it evident that while a hsien need not die, still less is it necessary to die to become a hsien. How then can be explained away the awkward fact that eminent votaries of $T A O$ suffer what to the vulgar eye differs not from the death of unregenerate man? The Taoists answer by likening the corpse to the skin shed by a snake, and the event they call a "dissolution" or "release from the flesh." 1 Be it noted that it is no discarnate soul that is thus liberated, but one animating an etherealized counterpart of its former earthly tenement.

Less ambiguity obtains when it is described how the coffins of such seeming victims of the universal fate are subsequently opened and found to contain nothing, except perhaps some grave-clothes. These are, of course, merely instances of hsien who for some good purpose feign death while awaiting translation to paradise.

No room for doubt is left when the happy one levitates to heaven, or is carried thither, like Elijah, in a celestial chariot, or ascends on high riding a phoenix, a crane, or a dragon. Clearly this numerous class retain their full bodily equipment, which may or may not have been prepared by a refining process of spiritualization. There is in this connection a curious point so frequently insisted on in Taoișt books that it cannot be passed over in silence. Great importance is attached to the particular period of the twenty-four hours in which the apotheosis of a hsien takes place, and apparently the hour varies to suit the sanctity of the individual. Release in the broad light of day is the most perfect, it is less so when it happens at midnight. When it occurs at dawn or at dusk, the being concerned is relegated to a terrestrial paradise such as the Isles of the Blest."

\footnotetext{
${ }^{1}$ Shik chich, v.J. K. As, Soc, 1916, p. 783 note. $2 v . J$. R. As. Soc, loc. cit.
} 
Naturally such easily assailable doctrines as these have not escaped the attacks of hostile critics. Most notable among them is the first century writer Wang $\mathrm{Ch}^{\prime}$ ung, an uncompromising materialist and bitter foe to any kind of imaginative belief. He exposes in detail the fallacies contained in many of the notions I have just sketched, and it is rather surprising to find our Isles missing from his list of Taoist superstitions. ${ }^{1}$

Finally, it must not be forgotten that hsien are subject to the law of rebirth; at least, so it appears from the many legends of their avatars. Here Indian influence may be traced. It is improbable that belief in metempsychosis was prevalent in China before the advent of Buddhism, though Chuang Tzŭ in the closing sentence of Book III. seems to sanction it. ${ }^{2}$ Surely reincarnation is inconsistent with the principle of physical inviolability claimed for hsien, unless their protean facility of transformation solves the riddle.

Transformation is only one of many superhuman powers possessed by perfect Taoist adepts. It is sufficient to mention that they can ride upon the wind, pass through water without becoming wet, and through fire without being burnt. ${ }^{3}$

Lest I be taxed with taking too materialistic a view, I would hasten to explain that what I have described has little to do with philosophical and mystical Taoism. This teaching, often called "Primitive Taoism," is preserved to us in the TAO Tr Ching ascribed to Lao Tzŭ, and in the Book of Chuang Tžr. Certain of their passages, it is true, seem to recognise the possibility of evading the common fate of man, yet the purpose of the writers is apparently to discountenance a striving after carnate immortality and its attendant magical practices.

\footnotetext{
'v. Forke, lun-HAn, i. pp. 325-350.

${ }^{2}$ Legge, S.R. E. xxxix, p. 202.

${ }^{3}$ Legge, op. cit. p. 237.
} 
Nor is there any mention in them of the Isles of the Blest. ${ }^{1}$

The foregoing summary of the rationale of hsienship conveys my impressions after reading a number of Taoist biographies or hero-tales, and I venture to think it represents the popular view, which is the one we are concerned with in dealing with folk-lore. How far back such ideas existed side by side with "Primitive Taoism" it is im. possible to say. I am inclined to think that their antiquity is generally underestimated. An any rate they were probably coeval with, if not earlier than, the notion of the island Elysium-a question to be discussed later.

Lao Tzŭ lived in the sixth century B.c.; Chuang Tzŭ some two hundred years later. Between them in time appears the dim figure of Lieh Tzŭ, whom many regard as a creation of Taoist imagination. Even if there was no such actual person, it is likely that a large part of the book connected with his name was written as early as the fourth century B.c. Probably some of its passages are of a later date, and perhaps the following description of the Isles of the Blest is one of them-a view that may be thought to find support from the silence on that subject observed by Chuang Tzŭ, and from the fact that elscwhere in the Book of Lich Tză emphasis is laid on the futility of attempting to prolong the allotted span of life. ${ }^{2}$

\footnotetext{
${ }^{7}$ Unless Ku-shê chih Shan, alluded to in the frrst chapter of Chuang $\mathrm{T} z \mathrm{u}$, may be regarded as an island paradise. The inhabitants are called shin jin, spirit-like beings, a term hardly synonymous with hsien, though the description of them is consistent with the recognised characteristics of hsien. The passage runs as follows: "Far away on the Isle of Ku-shê there dwell spirit-like beings whose tlesh is [smooth] as ice and [white] as snow, and whose demeanour is as gentle and unassertive as that of a young girl. They eat not of the Five Grains, but live on air and dew. They ride upon the clouds with flying dragons for their teams, and ruam beyond the Four Seas. The shen influences that pervade that isle preserve all creatures from petty maladies and mortal ills, and ensure abundant crops every year."

$$
\text { "v. I. Giles, Taoist Terinings, p. I5. }
$$
}


The passage reads thus :-

"To the east of the gulf [i.e., the Gulf of Chitli] -it is not known how many myriads of $l i$ distant-there is an ocean, vast in extent, and, in very truth, bottomless. In its fathomless depths is the so-called 'Abyss of Assembly,' to which the waters from the eight points of the compass and from the uttermost parts of the earth, and from the streams of the Milky Way all flow. And this they do without causing any appreciable change in the depth of the 'Abyss.'

Here lie the Five Isles, named Tai Yü, Yüan Chiao, Fang Hu, Ying Chou, and P'êng-lai. In height and round its base each island measures $30,000 \mathrm{li}$, and the circumference of the plateau on the summit of each is 9,000 li. Each is separated from its neighbours by a distance of $70,000 \mathrm{li}$. Upon their shores the terraces and pleasure-towers are built of gold and jade, and the birds and beasts are all alike of unblemished white. Thick groves there are, laden with pearls and gems, and not a flower but gives forth fragrant perfume, nor a fruit but has delicious flavour. On those who eat thereof is conferred the boon of youth and immortality. The inhahitants are all hsien and holy sages, ${ }^{1}$ who pass their days in happy companionship, which the intervening ocean channels do not interrupt, for they float through the air from isle to isle in countless numbers.

Now originally the bases of these Five Islands were not anchored to any actual spot, and in consequence they always followed the movements of the tides, up and down and to and fro, so that never for a moment were they firmly fixed. Such instability greatly annoyed the hien and holy sages, and therefore they laid a plaint about it before the Supreme Ruler of the Universe. He, fearing that the islands might drift away to the western confines of the world, and the abode of the saintly hosts thus become lost, commissioned the Great Yü to put a limit to their peregrinations. The latter told off fifteen gigantic turtles to support the islands upon their heads. They were divided into three shifts of five each, each shift being relieved

1 Shing, here meaning profound illuminates of $7 A O$. The term is also used to describe Confucius and other semi-deified sages of antiquity. 
once every sixty thousand years. Thus the Five Islands were at last immovably fixed.

But a giant of the Lung-po country, setting out on his travels, had not taken many strides before he came to the region of the Five Islands, when with one cast of his line he hooked six of the turtles. Then, carrying them all on his back, he returned whence he came, and their shells he used for divination by the scorching process. 1 Thus robbed of their support, the two islands of Yai Yü and Yüan Chiao, after drifting off towards the North Pole, were lost in the vast deep; and the hsien and holy sages, reckoned to number many hundreds of thousands, were thereby cut off from communication with their fellows.

When he heard of it, the Supreme Ruler of the Universe flew into a rage, and in order to punish the Lung.po country, diminished the size of its territory, and, also, reduced the stature of its people. Nevertheless, at the time of Fu Hsi and Shên Nung [i.e., in the legendary period, some 3,000 years B.c.] they still measured several hundred feet in height." 2

The next account to be quoted comes from the pen of the great historian Ssü-ma Ch'ien, aptly termed the Herodotus of China. His Historical Record ${ }^{3}$ covers a period of approximately the first 3,000 years of Chinese history, and the following may be accepted as a summary of the belief in the Isles of the Blest prevalent towards the end of the second century B.C., the time when it was written. The passage is specially interesting, because its author was sceptical in regard to the claims and propaganda of the professional Taoists ; indeed, elsewhere he openly discredits

${ }^{1}{ }^{1}$ For an account of this method, $v$. Couling, f. N.C. Br., N.A.S, vol. xly. centuries, about the oracle-bones, which, having lain buried for some thirty list of the were in 1899 djucovered in the province of IIman. It contains a a $L$ ied 7 thature on the subject.

Rieh Tat, v. 3 .

IShih $\mathrm{Chi}_{1}$ comprising 130 chapters, of which the first 47 have been rendered
accessilule to Western mental work entern readers by the late Prof. Ed. Chavannes in his monuProf. Chavannestled Al'moires Historiques de Se-ma T'tien, 1895-1905. pp. 42, 51.55, has been followed to a great extent in the translations on 
them and their doings. Speaking of the Three Islands P'êng-lai, Fang-chang, and Ying-chou, he says:

"Tradition has it that they lie in the middle of the P'o Sea [i.e., the Gulf of Chibli]. They are not far beyond the confines of humanity, but the trouble is that as soon as a ship approaches them it is driven away by the wind. In bygone days, it is true, some managed to come quite close to them. Hsien and the drug of immortality are to be found there, and there all creatures, birds and four-footed beasts, are white. Moreover, there the palaces and gates are built of yellow gold and wilver.

[Voyagers], while yet afar off, see the island as in a cloud; as they draw closer the Three Enchanted Isles ${ }^{1}$ sink beneath the waves; and when nearer still the wind suddenly takes their barque and carries it away. In short, no one has succeeded in gaining their shores, though not a prince but has longed to reach them." 3

Details lacking in the foregoing accounts may be found in a book called the Record of the Ten Islands, ${ }^{9}$ often ascribed to a famous Taoist who lived during the second century B.c., though crities assign to it a much later date. The writer, whoever he may be, catalogues in turn the marvels of the Five Islands. In place of those said by Lich Trŭ to have drifted away and become lost, he describes two under the names of Tsu Chou and Shêng Chou; and, in contradiction to the statement of Ssur-ma $\mathrm{Ch}^{\prime} i \mathrm{cn}$, he places the group at fabulous distances from the coast of China, synonymous then with the eastern limit of the known world. In one instance, for example, the distance is estimated at a quarter million miles. An idea of the general felicity pervading that happy land is conveyed by the description of a mild, equable climate, and abundant nourishment easily procurahle by all.

1 San shitn shan.

ashih Chi, xxviii. if v.

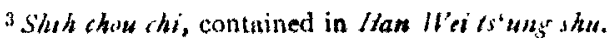

the magician, courtier, and mystic Tung-fang Shuo. He is credited with the authorship of other Tauist works. v. Giles, Biog. Dict. No. 2 c93. 
He gives particulars of the agencies to be found there that offer escape from the physical evils of this earth, nay more, that actually confer immortality and restore life to the dead. In one island from a precious (lit. " jade") rock 10,000 feet high there flows a spring tasting like sweet wine. Whoso drink of it pass through a short period of intoxication to a life indefinitely prolonged beyond the normal span. A spring with nine founts is also spoken of ; and in another island all the waters have the flavour of sugar and milk. But more potent still in their vitalizing properties are certain plants, and chief among them are various kinds of fungi collectively called chih.

The writer tells in what rich profusion they grow upon the islands. In Fang-chang, for example, the crops of chih cultivated by the hsien are likened in abundance to fields of rice. Another island, Tsu Chou, produces a variety called "the chih that feeds one's vital spirit," 1 so powerful in its workings that mere contact suffices to bring back life to corpses three days after death-a fact once signally proved when some ravens carried the plant in their beaks
over to China and dropped it upon the faces of the slain.

The Record of the Ten Islands also gives illuminating details Concerning the beings who people the island Otherworld. The great majority belong to the class of hsien, but it is P'eng-lai is accessible only to those who can fly, and another island is the chosen resort of hsien who have abandoned desire to reach celestial regions. There are, besides, beings on more exalted planes. In palaces of heavenly splendour on the peaks of P'eng-lai there live some who rank among the "holiest of adepts, ${ }^{2}$ certain of whom bear the title of the "Nine Ancient Worthies." I Furthermore, in Fang-chang the "Arbiters of Destiny of the Three Heavens" hold their court, and it seems that they very nearly, if not

\footnotetext{
'Yang shins chih.

${ }^{3}$ Chin las chang joth.

"T"ai shang chln jitn.

+ San licu s.rĩ ming.
} 
quite, reach the dignity of godship. The same might be said of the "Chief of the Community of Elders" 1 who there exercises sovereignty over the spirits of all aquatic animals of the world.

Time does not permit an attempt to enumerate all the wonders of the Five Islands. Taoist writers dilate upon their gorgeous palaces, their gay-plumaged birds, and their gemmeous vegetation. Nor have we even exhausted the mine of information to be found in the Record of the Ten Islands. One island, distinct from the five, therein described as lying far off in the eastern main, must not be left unmentioned, if for no other reason than that it has been the subject of speculation and controversy among Western scholars, some of whom have sought to prove a Chinese discovery of America many centuries before Columbus. This, the "Country of the Leaning Mulberry" (Fu-sang), is named after its forests of gigantic mulberry trees, growing in twos, with the trees of each pair inclined together. They bear their fruit but once in nine thousand years, and hsien who eat thereof become lustrous with golden glory, and endowed with the power of roaming the skies.

It should moreover be noted that the Eastern Sea is not the only site of ocean paradises inhabited by hsien, and containing agencies of immortality. Assuming the truth of the ancient fiction that China constitutes the world and is surrounded by four seas, some Taoist fabulists have allotted to the remaining points of the compass islands similar in many ways to those I have described. This extension of the overseas Otherworld may be regarded as the literary fintasy of a few imaginative enthusiasts, and not as representing the popular conception that has been current in China for more than twenty centuries. In general literature and in common parlance, the Isles of the Blest are a group lying somewhere to the east, and 
they are usually spoken of as the "Three Hsien Islands" or "Hills," or simply the "Three Islands," by which is meant the three best known, namely, P'êng-lai, Fang-chang and Ying Chou. P'cing-lai is the most famous of all, and it is often used alone to represent the group. Horaizan, its equivalent, is the name under which the Chinese conception has been adopted into Japanese legend. ${ }^{1}$

All that I have so far said has been derived from written sources, yet no study of the subject would be complete without taking into account the productions of countless artists and craftsmen, to whose genius must be largely attributed the persistence and popularity of the island Elysium tradition. To them this and kindred themes have been a never-failing inspiration. Their work shows joy in a congenial subject, and the joy shines forth whether the treatment is marked by reverential fervour or by a spirit of half-humorous antiquarianism. Every one of China's millions is familiar with the pictured forms of certain of the $h s i e n$, and in the world's history probably no
object has been represented more often than the magic
fungus, fungus, ${ }^{2}$ standing as it does the emblem par excellence for
Taoist Taoist longevity.

To Chinese artistry add the floating folk-lore of the country and we have the chief machinery through which belief in the Isles of the Blest and their immortal inhabitants has been kept alive in the fancies arrd affections of the 'Joly, Legemd in Jaf. Ant, pp. 126, 239, 386 srg.

"The kind appearing in pictures and in all forms of decorative art is generally branches chin, the "chih possessed of spirit-power." It is shown having edges, thus resemand into flattened umbilicated extremities with scolloped gives the various bong a fungus known to science. Bretschneider in Bot. Sirn. is partly traceable to nical names it has received. Its emblematic significance it is to some extent the resistance offered by its substance to decay, and hence its import see De Groogous to the French immortelle. For other aspects of magic qualities havinot, Rel. Sys, of China, vol. iv. There are records of its $\mathrm{pp} .54,55)$, and to the present day it is arly as the third century 8.C. (7) inf. capable of prolonging life. 
people. In this respect the voluminous mass of Taoist literature must take a secondary place.

We are now in a position to sum up the Chinese concep. tion of their island Elysium.

It is somewhere to the East, in mid-ocean, beyond the ken of man. Accounts differ as to the number of the islands, but popular fancy has crystallized them into a group of three. To mortals who search for them, they prove elusive and unattainable. There Nature, always in her most beneficent mood, satisfies every physical desire. Nay more, the jewelled splendours there surpass all mun. dane beauty, whether the work of Nature or of man. Most precious of all are certain vitalizing plants and fountains of life, all of which confer the boon of deathlessness as well as immunity from the infirmities and limitations of the flesh.

Entrance to this enchanted land lies not through the portals of death, for alone hsien and more exalted illuminates of TAO people its shores, and share its bliss with etherealized counterparts of earthly birds and beasts. These happy ones pass their days in intellectual companion. ship varied with full enjoyment of sensuous delights, innocent enough from all accounts, unless exception be taken to the amiable scenes of bibulous revelry that artists love to portray.

Let us look round the world for conceptions analogous to this. Many are to be found, but time imposes a limited choice, and it seems best to confine the survey to the closest parallels occurring among our own kin, the Aryan-speaking races.

One example is Sukhãvati, the Happy Universe of the West, presided over by the Buddha Amitābha. Brahmanic in its ultimate origin, it exercises a strong hold on the imagination of Chinese and Japanese Buddhists to the present day.

Its gorgeous beauty, described with such rich detail and 
glowing metaphor in the sutras devoted to it,' has doubtless stirred to emulation many of the later Taoist writers. A parallel to the magic fungus is found in its gigantic tree that gives immunity from all the ills of the flesh. Further, it agrees with the Chinese island Elysium in its abundant provision for all physical needs, and in the absence of those amorous delights that figure so prominently in Western ocean paradises. The inhabitants of Sukhaveati live for ages, but not for ever, because they are candidates for Buddhahood. Neither are they translated thither in the bodies tenanted on earth, but are born from lotuses within the paradise.

Vuru, similar is the Hindu northern paradise of Uttera. kuru, peopled by beings who have acquired perfection by the magic means of $y \circ g a$, and in them we see a resemblance to hsien. They reach this inaccessible land by being dropped from the skies. The same miraculous tree exempts them from disease and decay, and they live the same round of sensuous pleasures. At length, after many centuries, they die, and their corpses are removed to mountain caves by fabulous birds. ${ }^{2}$ One account gives a sexual side to the joys of Uttera-kuru. ${ }^{3}$ The Grecian version of this northern paradise is inhabited
by the Hyperboreans. Here again death ends long years of blissful existence; for, when surfeited with the joys of life, the Hyperboreans leap from a rock into the sea." The foregoing examples all differ from the Far Eastern
paradise in their association with death. In ancient Grecce and Ireland are to be found notions more nearly resembling the Chinese, because they are linked inseparably with carnate immortality, and are devoid of ethical or religious

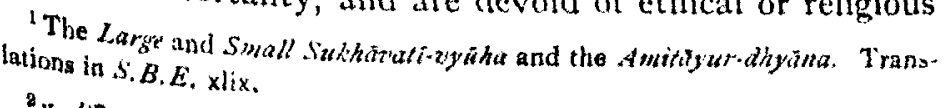

av. Kamidyana, iv.

"Mahabhisala, vi.

'Pliny, Hist. Nat. Bk, iv. cp. 12. 
design. No call for reward of human righteousness occasions them, nor do they belong to a system of which hell is an integral part. The closeness of the analogy is scarcely lessened by the amorous complexion of Hellenic and Celtic paradisaical bliss; for it is only in keeping with Chinese literary tradition to omit any mention of the physical manifestation of love. Not that legend in China is altogether lacking in island abodes of superhuman females who are fain to receive the embraces of mortal lovers ; ${ }^{1}$ yet, so far as I know, such a notion has never entered into the Isles of the Blest conception. ${ }^{2}$

In the Homeric poems the joys of an everlasting earthly paradise are reserved for the few, who are heroes of divine descent specially favoured by the gods or the chosen mates of amorous goddesses. ${ }^{3}$ Immortality is conferred upon them by the eating of ambrosia, by the drinking of nectar, or simply by divine caprice.

The Elysian plain prophesied to Menelaus ' is a poetical creation unrelated to any actual locality such as Strabo assigns it. ${ }^{5}$ Like all earthly paradise conceptions, its essence lies in its remoteness from human ken. Hesiod, robbing it of none of its mystery, places the happy land in the ocean, and he first uses the name "Isles of the Blest,"

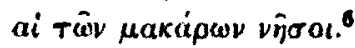

In Pindar the delights of the overseas Elysium are told in similar terms, ${ }^{7}$ but the idea has lost its archaic simplicity. It becomes religious. Admission is gained only through death and subsequent lives of merit lived upon earth. At

'Schlegel, T'ong Pao, vi. p. $247 \mathrm{se}$.

"It is, however, known to Tanism. In one of the biographies of the Lieh hsien chuan of Liu Hsiang a female hsien figures in much the same rôle as a priestess of Astarte.

"r.s. Calypso, Od. v. + Oll, iv.

"čos. Bk. i. cp. i. 8 4, 5: Bk. iii. cp. ii. 13 .

- Works and Days, lines 167 seq.

Ind Ol. Ode. 
this point the Grecian diverges from the Chinese type, and so we trace it no later in its development.

In Celtic, as in Hellenic myth, it is the primitive con. ception that offers the closest parallel to the Chinese. By primitive is meant pagan Celtic, before it became tinged with Christianity. Of this a famous and representative example is the tale of Bran's voyage. Here we find a numerous group of large islands lying to the west of Ireland figuring as the earthly paradise. It is a land of entranc. ing beauty and of abundance satisfying all physical desires. A wonderful tree is there, but apparently it is not to any magic virtue of its fruit that the inhabitants owe their inmunity from death and the infirmities of the fesh. ${ }^{2}$ Mortals while still in life gain admission at the invitation of the superhuman beings whose abode it is, and on reaching its shores become endowed with the privileges enjoyed by their hosts. One feature of the hospitality extended to Bran and his followers by the queen and her maids is described in very unequivocal language, which, as the author of the well-known book on the subject aptly remarks, might be used appropriately in connection with Hampstead Heath on an August Bank Holiday evening." As I have is is ady stated, in this last respect the analogy fails. But is it stretching parallelism too far to find another point of likeness to the Chinese Isles of the Blest in Manannan, the lord of the Irish Elysium? $\mathrm{He}$ is also a god of the sea, a sort of Celtic Poseidon, and in this capacity seems strangely chan to the semi-divine being who from the isle of Fang. Instang over all the denizens of the ocean."

Instances might be multiplied of beliefs conforming to the Chinese type in their essentials. A remote and unknown land, difficult of access, lying in the direction of the rising or setting sun, and of ten overseas. To it certain favoured ${ }^{1}$ 's. Nutt and Meyer, Voyage of Bran, vol. i.

${ }^{2}$ Nuts and Meyer, op. cit. p. 6.
'v. sup. p. 44 .

"Nuut and Meyey, op, cit, pp. 20, 290. 
mortals gain admission, sometimes without dying. There the blest enjoy for ages a glorified continuation of their earthly existence, and there magic trees or fountains of life ensure immunity from all physical ills and death. Such notions characterize the imaginings of many primitive and savage peoples all the world over. Does the sameness of the conception in the examples I have quoted, and in many I have had to pass unnoticed, postulate a general borrowing or a derivation from a common origin? I think not.

It might seem reasonable to trace the Chinese notion to Indian sources, through the Buddhist Sukhāvati ultimately to its prototype, the Brahmanic western paradise of Varuna, or directly to the latter. Such a theory would be difficult to prove. Some have claimed an Indian origin for the whole system of Taoism. On the other hand, Prof. Parker ${ }^{1}$ discusses the plausibility of the tale that Lao Tzŭ emerged, after his disappearance from China into the West, to become himself the founder of Buddhism. Our knowledge of the mutual indebtedness between China and India in ancient times is hazy in the extreme. Even A.D. 67, the date generally accepted for the introduction of Buddhism into China, may be two or three centuries later than the actual event. ${ }^{2}$ Then too, though it is not a very forcible argument, the Sukhãvativyūha was not translated into Chinese before the middle of the second century of our era; ${ }^{3}$ and belief in the China island paradise is certainly more than five centuries older, as I shall show presently.

Less likely does it seem that a borrowing took place from ancient Mediterranean sources, though it is safer not to be too dogmatic when so many problems, notably in the realm of art, connected with the Grecian occupation of India remain unsolved. The pendulum of present day opinion

1 China and Religion, pp. 10, 81.

"v. Gilex, Confucianism and its Rivals, p. 165 seg.

"Nanjio, Cat. of Chin. Budd. Trip. No. 23 (5) note. 
in these matters appears to be swinging the other way, and it is the fashion to find influences flowing from East to West rather than in the opposite direction.

In a word, I would venture to claim for the Chinese conception that it is indigenous, and propound a theory based upon the hypothesis of unity in human thought and aspirations, justified, I think, in the light of our survey. First, man's instinctive longing for a haven of rest from this world's tribulations found satisfaction in a nebulous paradise imagined in the East, the quarter specially associated with the celestial vitalizing force called Yang, of which the quintessence is the sun. No date can be assigned, except that by the fourth century B.c. the notion was sufficiently established to lead a feudal prince to make search for the Isles of the Blest. At that time the Chinese national vision of an after-life was as cheerless as that vouchsafed to Ulysses in his descent into Hades, and Buddhism with its promise of salvation had not yet arrived. We can picture the belief eagerly accepted by a people yearning for a happier fate, and hope stimulated by ex. aggerated tales of sailors' discoveries, as it was in our own classical instances of the Carthaginians ${ }^{1}$ and Sertorius. ${ }^{2}$ Thus the island paradise took definite shape in the East as did the Insulae Fortunatae in the West.

The Chinese Isles first appear in the pages of authentic history in association with the less reputable exponents of T.AO-men who thrust themselves into notice while inter. preting and exploiting the doctrine to suit their own ends. in in the remaining part of the paper, which deals with the historical development of our subject. Thus Ssŭ-ma Ch'ien, after mentioning five Taoists by
name, says-

" They were all natives of Yen, who practised Taoistic magic, in order that their bodies might become released from earthly 'v. inf. pp. 60, 6r.

- Plutarch, Sertorius. 
trammels, refined (like smelted ore), and transformed. They relied upon the cult of the kuei and the shên. ${ }^{1}$ Tsou Yen ${ }^{2}$ was famed among various feudal princes for his treatise on the control exercised by the Yin and the Yang over evolution. The magicians, who inhabited the coastal regions of Yen and $\mathrm{Ch}^{\prime} \mathrm{i}$ handed down his mystic doctrines without being able to understand them. Moreover, then it was that men versed in strange wonders and deceitful flattery, and knowing how to ingratiate themselves with the people by base means, multiplied in countless numbers. The sending of men to sea in search of P'êng-lai, Fang-chang, and Ying Chou dates from the time of Wei and Hsüan and Chao of Yen." 3

We know that Prince Wei ruled over the State of $\mathrm{Ch}^{\text {' } \mathrm{i}}$ from B.c. 378 to 333 , and Hsüan was the name of his successor. Prince Chao ascended the throne of Yen in 3II. This passage, therefore, provides a highly important fact, namely, that belief in the Isles nearly 400 years before Christ was sufficiently robust to encourage the fitting out of expeditions to search the seas for them. The statement may be accepted without reservation, especially in view of the freedom from partiality shown by the writer. It is evident that Ssŭ-ma Ch'jen was not one of those taken in by Taoist adventurers, who would naturally claim the sanction of antiquity for their doctrines. Indeed, one of them is quoted as describing meetings between the Yellow Emperor and the inhabitants of P'êng.lai." Such an early date for the belief was undoubtedly imaginary, and though we may suppose the notion existed some time before the first

' $X$ "wei is the material soul emanating from the terrestrial part of the Cusmos, and is therefore associated with Yin. Shen is the ethereal soul emanating from celestial sources and is associated ith Yang. The Chinese attribute these two souls to man in common with the rest of creation. v. De Groot, Kel. Sys. of China, iv. especially pp. $5,52$.

" $v$. Giles, Biog. Dict. No. 2030. Tsou Yen lived in the latter part of the fourth century B.C.

S.Shih Chi, xxviii. p. Is.

4 Chavannes, of, cit. iii. p. 498. 
expedition of discovery, it cannot be traced with historical certainty beyond the beginning of the fourth century B.c.

It is necessary here to say a word of geographical explanation. China of the period we are discussing covered a much smaller area than it does to-day. Its extreme north-eastern frontiers were those of the feudal State of $\mathrm{Yen}_{\mathrm{en}}$ which roughly corresponded in extent with the modern province of Chihli, and had its capital close to where Peking now stands. The State of $\mathrm{Ch}^{\prime} \mathrm{i}$ adjoined Yen on the south, and like it had a seaboard opening on to what was afterwards called the Gulf of Chihli.

Another name frequently mentioned in recording the peregrinations of Taoistically-minded emperors is Lang-yeh. This was certainly a coastal region, though whether in the north or south of the present Shantung is doubtful. Thus $\mathrm{Yen}_{\mathrm{en}} \mathrm{Ch}^{\mathrm{i}} \mathrm{i}$, and Lang-yeh adjoined and formed the north. eastern corner of China bordering on the sea.

The passages I am quoting indicate that, if this part was not the actual birthplace of the conception, it was, at any wate, here that it first grew and flourished. It is a noteworthy fact, that to the present day it retains its reputation as a stronghold of Taoism. Returning to the narrative told in the pages of the
Historical Record, we next come upon the famous emperor Who, not without reason, has been styled the Napoleon of ings were will be seen how fervently his thoughts and longaspiration centred in the Isles of the Blest, and how his turers. It continurtality were exploited by Taoist adven-

"Furthermore, at thus :-

under the rule of at the time when China had become united travelled to the sea coast. Then magicians in countless numbers discussed the Three Enchanted Islands. The Emperor feared lest, if he himself embarked upon the sea, he might not succeed
in reaching the search, whom he So he commissioned someone to make the 
maidens. Their ship sailed across mid-ocean. The excuse they gave for failure was the plea of contrary winds, declaring that they had been unable to get to the Isles, though they had seen them from afar. The following year (B.C. 2I8) the Emperor returned to the coast, and wandered till he came to Lang-yeh. ... Three years later (B.c. 2I5) he journeyed to Chieh-shih, ${ }^{2}$ and put questions to those magicians who had explored the sea. ... Five years after that (B.c. 210) the Emperor travelled to the south as far as Mount Hsiang. ${ }^{2}$ Next he climbed Kuei-chi. ${ }^{8}$ He kept along by the sea coast in the hopes of coming upon the marvellous herb (i.e., the magic fungus) of the Three Enchanted Islands that lie in the middle of the ocean, but failed to obtain it. On the return journey the Emperor died when Sha - ch'iu $^{6}$ was reached." $s$

Thus ended the First Emperor's quest for immortality. His famous expedition of B.C. 219 is mentioned in other parts of the Historical Record. The passage that provides the fullest details infers that it was not his first attempt of the kind. It runs as follows :-

"In bygone days the $\mathrm{Ch}$ 'in Emperor... sent Hsü $\mathrm{Fu}$ to sea in search of supernatural and strange things. On his return he made lying excuses, saying: 'Your servant saw in mid-ocean a great Spirit who asked: Are you the envoy of the Emperor of the West? Your servant answered, Yes. What have you come to seek? said he. To which your servant replied: I would request of you the herb that lengthens one's years and increases longevity. The Spirit said: The offerings of your Emperor are inadequate; you may look at the herb, but not take it. Then he accompanied your servant towards the south. east till we arrived at the Island of P'êng-lai. I saw the portal of the hall where are stored the crops of magic fungus. By it stood

${ }^{1}$ A mountain in Yen near the const on the north side of the Gulf.

${ }^{2}$ In the extreme south-west of his empire, near the capital of the modern province of IIunan.

${ }^{3}$ A mountain near the coast on the south side of the Bay of IIang-chou.

'A region near Shun-tê in Chihli. Chavannes, of. cit. i. p. 200.

Shih Chi, xxvili. pp. 11 v. $12 \mathrm{r}$. 
an emissary, who was the colour of brass, and had the form of a dragon. There shone from him rays illuminating the sky. Prostrating myself twice I asked him, saying: What gifts would be acceptable to the Ocean Spirit? He answered: Well. born youths and young virgins, together with craftsmen of all kinds. Thus the herb may be obtained.'

This delighted the Ch'in Emperor, who sent three thousand youths and maidens, as well as seeds of the five kinds of grain and artificers of all kinds. Then Hsủ Fu set sail, and found a peaceful and fertile land. There he stopped and made himself king, and returned not." 1

This ending of the tale hardly tallies with that told much earlier in the Record. Apparently the event there described took place just before the Emperor's death, and nine years after he had despatched the great expedition. He is shown again skirting the sea-shore in the course of one of his frequent tours of the empire, still loth to abandon hope of meeting some sailor from whom he might gain possession of the magic plant of immortality. The passage runs thus :

"The magician Hsü Shih and others had sailed in quest of the herb of immortality, and several years had passed without their having found it. Because of the great wealth expended thereon, and their consequent fear of blame, they made the following false statement: "It is possible to find the herb of P'êng-lai, but we have always been prevented by the great shark, and that is why we have failed to reach it. We would propose that a good archer bi added to our company, so that when the fish appears he will shoot arrows at it from a cross-bow so made that several can be discharged in quick succession." "g

'Shih Chi, cxviii, p. It.

${ }^{2}$ Shith Chi, vi. p. $27 \mathrm{x}$. In connection with the two foregoing passages, sculer, Opin Court, lune 1913, interprets a scene in one of the famous Ian fungus from representing the envoy of the First Emperor requesting the magic profect the Ucean Spirit, who with his guarls and marine monsters shared by sanctity of the Isles of the Blest. This view is not, however, Yellow Chavames, who sees in the bas-relief a picture of the Lord of the Chine River suirounded by his aquatic subjects. Miss. Archeol, dans la Chine Sept, i. pp. 207, 208, 28\%. 
We learn that the Emperor accepted this explanation, and ordered that future expeditions should be provided with apparatus for catching the great shark. He even went so far as to arm himself with a cross-bow for his seaside excursions, and while on one of them shot a large fish with his own hand.

This aecount of the disappointed members of the expedition having returned to China is inconsistent with the colony theory about which I shall have more to say later. There are other variants of the story. For instance, the statesman and author, Liu Hsiang, who was born about the time Ssŭ-ma Ch'ien died, in one of his Taoist biographies traces the inception of the project to a famous magician named An-ch' $i .{ }^{1}$ Also he estimates the personnel of the expedition at the comparatively modest figure of "several hundreds." And the writer of the Record of the Ten Islands says they numbered five hundred. ${ }^{2}$

A pitiable figure is that of the First Emperor during the last decade of his brilliant reign. We see the conqueror of the world (as the Chinese knew it) obsessed with frantic desire to obtain the secret of the Enchanted Islands in his longing to escape death. He spends his days feverishly roaming the ocean brink, and anxiously interviewing any who might give news of the Islands and their magic agencies. For three successive days and nights he remains in consultation with the magician An- $\mathrm{Ch}^{\prime} \mathrm{i},{ }^{3}$ and there are other similar tales." Bereft of his normal senses, he becomes the easy dupe of Taoist vagabonds, however fantastic their claims and projects. Towards the end, the Emperor's credulity turns into suspicion and rage, and we find him ordering 460 scholars and magicians to be put to death, chiefly, it

'Jieh hsicn chuan, i. p. 9. Critics, however, assign this book to a later date.

$\therefore$ Account of Tsu Chou.

s Lieh hsien chwan, i. p. 9.

'Chavannes, Mt'm. Hist, ii. pp. $164 \mathrm{seq} .176 \mathrm{seq} .183$. 
seems, because they had failed him in the quest of the magic herb. ${ }^{1}$

Six sovereigns occupied the throne of China during the scventy years following the death of the First Emperor. Some favoured Taoism, but it was not till the accession of $\mathrm{Wu} \mathrm{Ti}$ in B.c. I 40 that the cult of immortality obsessed the thoughts of an emperor. $\mathrm{Wu} \mathrm{Ti}$ was not contented with merely searching for the Isles of the Blest. His revival of the ancient sacrifices in honour of heaven and earth ${ }^{2}$ was apparently the outcome of the magicians' repeated assurances that by so doing he would attain hsienship, and, like the Yellow Emperor, be translated to paradise without dying. ${ }^{3}$ The same motive led him to recognise officially the art of alchemy. The following is important as the earliest historical account of Chinese alchemy. It refers to the year I 33 B.c.

"Shao-chün'said to the Emperor: 'Sacrifice to the crucible, and you will be able to make supernatural beings appear. When you have effected their attendance, cinnabar can be transmuted into yellow gold. Having obtained yellow gold, you can fashion it into vessels for drinking and eating, and thus extend your longevity. When your powers of long life have been increased you will be able to see the hsien who live on the Island of P'êng-lai that is in mid-ocean. When you have seen them, and have also performed the sacrifices in honour of heaven and earth, you will become immortal. It was thus with the Yellow Emperor. Your servant, in the course of his constant wander. ings at sea, has seen the Master An-ch'i, who was eating dates as large as melons. The Master An-ch'i is a hsien, and he frequents P'êng-lai. He can make himself visible or invisible to mortals as it pleases him.'

It was in consequence of this discourse that the Son of Heaven personally offered for the first time sacrifices to the crucible.

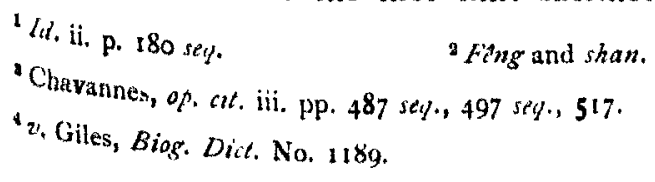


He also sent magicians to sea to search for P'êng-lai and the Master An-ch'i. Then he turned his attention to transmuting cinnabar and scraps of every kind of drug in order to get yellow gold.

Some time after that $\mathrm{Li}$ Shao-chün fell ill and died. The Son of Heaven, thinking that he was not dead but merely departed in a transformed shape, commissioned $\mathrm{K}^{\prime}$ uan Shu, a secretary in the prefectures of Huang and Chiu, to continue the magical practices of $\mathrm{Li}$ Shao-chün, and the search for P'êng-lai, and for the Master An-ch'i. But they could not be found. Moreover, in the region of Yen and $\mathrm{Ch}^{\prime} \mathrm{i}$, bordering on the sea, magicians skilled in strange marvels appeared in ever increasing numbers and engaged in discussions on spiritual matters." 1

To be a Taoist magician at the time of $\mathrm{Wu} \mathrm{Ti}$ was a profitable calling. The pages of Ssŭ-ma $\mathrm{Ch}^{\prime}$ ien are full of the honours showered upon a succession of these favourites. ${ }^{2}$ True, some of them came to a bad end. For instance, one within the space of a few months had conferred upon him the very highest honours, including an imperial princess as wife, and then was found out and executed by being cut in two. Another declared a certain bullock had a miraculous object inside it. The animal was killed, and, sure enough, within its stomach was found a message on a silken scroll. But the Emperor recognised the magician's handwriting, and he too suffered violent death. ${ }^{3}$ However, these were exceptions. Under the Emperor's orders thousands found employment in searching the seas for the Enchanted Islands, ${ }^{4}$ and hunting the countryside for hsien. ${ }^{5}$

$\mathrm{Wu} \mathrm{Ti}$, like the First Emperor, frequented the coast, interrogating seafaring folk, and hoping to catch sight of the Islands in the far distance. Facing eastwards, he sacrificed to the inhabitants of P'èng-lai. ${ }^{B}$ In the hope of

'Shih Chi, xxviii. pp. 23, 24 r. 2 Chavannes, of cit. iii. p. 470 seg.
"Id. p. 471.
'Ia. pp. 499, 506.
s.t. p. 500.
- Id. p. 513. 
entering into communication with hsien, and so learning their secret, he erected elaborate buildings for their reception if ever they could be persuaded to appear, and in one of these palaces he had models made of the Isles of the Blest. ${ }^{1}$

Enough has been said to trace the historical beginning and early development of the belief. It seems highly probable, almost certain in fact, that a vague knowledge of Japan contributed to its inception. This theory has been elaborated with great thoroughness by Schlegel, who finds a circumstantial origin for many of the wonders attributed to the Enchanted Islands. ${ }^{2}$ Their palaces were in fact the shrines and hermitages environed then as now with Nature's most entrancing scenes, and hsien were the priestly inhabitants. The Japanese have always been noted for longevity. The founts of magic elixir were the thermal springs, of which the curative properties were already recognised in that far-off age, and the abundant gems and fairy groves were but fanciful versions of actual pearl fisheries and submarine coral forests. There is, too, a passage in the Record of the Ten Islands which I have not yet quoted, and it seems strongly to support the theory. In describing Ying Chou it says :-

"There are many communities of hsien on the island, whose customs resemble those of the men of Wu. The mountains and rivers are like those of the Middle Kingdom."

Wu was a feudal state occupying a costal region of China corresponding to parts of Kiangsu and Chehkiang.

I have already drawn a geographical analogy between the Chinese Isles of the Blest and the Insulae Fortunatae. Both groups lay somewhere across the ocean, beyond the limits of the known world. The currency of both in folk. actual is be largely attributed to sailors' yarns about actual islands they had visited-tales which, like most

$$
\text { ' } d d \text {. p. } 514 \text {. }
$$

"T"oung Pao, vi, pp. 1-64. 
sailors' yarns, lost nothing in the telling. We have seen reason to identify the Chinese Elysium with certain Islands of the Japanese Archipelago; classical geographers evidently traced the Western conception to Madeira or the Canaries, ${ }^{1}$ or perhaps to the Azores.

Why, it may be asked, did mystery cuntinue for so long to surround both island groups? In the Far East the explanation is not to be found solely in the Chinese apathy towards geographical discovery so strikingly exemplified in their ignorance about Formosa up to quite recent years, though probably this factor contributed to the long life of the overseas Elysium conception. The proximate cause lay, I fancy, in the vested interests of the chief propagators of the notion-the professional Taoists, who naturally were loth to allow the veil to be torn aside from what was to them a source of livelihood only so long as it remained mysterious. Besides, they were anxious not to lose a safe asylum in case changes of fortune obliged them to flee the country.

This wilful suppression of fact had a striking parallel on the other side of the world, though motives differed. Diodorus ${ }^{2}$ tells how the Phoenicians discovered an island having such perfect natural conditions that it seemed "the abode of gods rather than of men." It was in mid-ocean to the west of Libya, and contrary to their intention they had been carried thither by an adverse wind. From them the Etrurians heard of it, and proposed to plant a colony there. But the Carthaginians vetoed the project, fearing lest the attractions of the island might rob them of their citizens, and wishing to keep secret such a ready refuge in adversity. In a book attributed to Aristotle ${ }^{3}$ the story is much the same, save that a Carthaginian colony is stated to have settled on the island, and that further immigration was forbidden on pain of death.

'Strabo, Geog. Bk. i. cp. 1, 85 ; Bk. iii. cp. 2, \$ 13. Pliny, Hist. Nat. Bk: vi. cp. 32. Ptolemy, Geog. Bk. iv. cp. 6.

${ }^{3}$ Bibl. Llist. Bk. v. cp. 2.

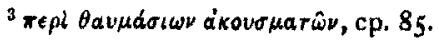


It is curious to reflect that in two widely separated parts of the world the first historical event connected with an overseas paradise took place not many years apart. Prince Wei's expedition left the coast of China early in the fourth century B.c.; Himilco's fleet passed through the Pillars of Hercules "in the flourishing days of Carthage." 1 The Carthaginians sailed up the coast of Spain and on across the Atlantic. While returning, they encountered islands af which their glowing accounts probably provided material for belief in the Insulae Fortunatae. ${ }^{3}$ The notion thus fostered lived on, and was from time to time revitalized by other sailors' tales, though as knowledge grew the Islands moved further westward. Then in the middle ages the imagination of the world was profoundly stirred by the ancient Irish myth of St. Brandan's Voyage, and many a mariner was tempted to seek the isles of immortality in the Western main. If Taoist aspirations led to the Chinese discovery of Japan, so belief in the Fortunate Islands contributed to the finding of the New World.

It remains to say a word about early Chinese colonisation of Japan. History and legend certainly indicate, I think, that Taoist adventurers frequently visited its shores, and the probability is that some of them settled there. Until A.D. 540 Japanese accounts of Chinese immigration are unfortunately vague. In that year "the men of $\mathrm{Ch}^{\text {in }}$ numbered in all 7053 houses." A European writer has calculated this to mean between 120,000 and 130,000 persons. ${ }^{b}$ If this estimate is correct, it may be imagined that active colonisation had being going on for several centuries.

The texts I have quoted leave in doubt whether the large expedition of B.c. 219 settled permanently in a foreign land

'Pliny, Hist. Nat. Bk. ii. cp. 67.

${ }^{2}$ Avienus, Ora Mar. lines $117,383,412$.
"Cf, Strabo, Geog. Bk. iii. cp. 2, 813, 14.

Aston, Nihongi, ii. p. 38 .

s Murdoch, Hist. of Japan, i. p. 102. 
or returned to China. Its leader, Hsü Fu, evidently intended to found a colony. Schlegel traces it to the Philippines. ${ }^{1}$ A tradition of the expedition exists in Japan, and is suff. ciently strong to have led to the erection of shrines in honour of $\mathrm{Hsü} \mathrm{Fu}^{2}$ and to the association of some graves. in Kii province with him and his followers. ${ }^{3}$ Against too much credence being placed in the corroborative value of ancient Japanese tradition is the fact, pointed out by Chavannes, ${ }^{4}$ that much of it is derived from Chinese sources.

Summing up the purely unimaginative side of this subject we find that, though hardly justified in claiming for the Isles of the Blest a close association with the origin of the Japanese race, we may with safety affirm that the conception powerfully stimulated early Chinese exploration and navigation of the seas. Whatever their faults, Taoist adventurers must share with Buddhist pilgrims the credit of having been pioneers in Chinese geographical discovery.

W. Perceval Yetrs.

1 Toung Pa, vi. p. 9.

2 Toung Pao, vi. p. 10.

${ }^{3}$ Brinkley, Hist. of the Jap. People, p. 78.

- Op. cit. ii. p. 15.3 . 